\title{
The democratisation of European nature governance 1992-2015: introducing the comparative nature governance index
}

\author{
Suzanne Kingston, et al. [full author details at the end of the article]
}

Accepted: 23 September 2021 / Published online: 27 October 2021

(c) The Author(s) 2021

\begin{abstract}
European environmental governance has radically transformed over the past two decades. While traditionally enforcement of environmental law has been the responsibility of public authorities (public authorities of the EU Member States, themselves policed by the European Commission), this paradigm has now taken a democratic turn. Led by changes in international environmental law and in particular the UNECE Aarhus Convention (UNECE, United Nations Economic Commission for Europe Convention (1998). Convention on access to information, public participation in decision-making and Access to Justice in Environmental Matters (the Aarhus Convention), signed on June 25, 1998.), EU law now gives important legal rights to members of the public and environmental nongovernmental organisations ("ENGOs") to become involved in environmental governance, by means of accessing environmental information, participating in environmental decisionmaking and bringing legal proceedings. While doctrinal legal and regulatory scholarship on this embrace of "bottom-up" private environmental governance is now substantial, there has been relatively little quantitative research in the field. This article represents a first step in mapping this evolution of environmental governance laws in the EU. We employ a leximetrics methodology, coding over 6000 environmental governance laws from three levels of legal sources (international, EU and national), to provide the first systematic data showing the transformation of European environmental governance regimes. We develop the Nature Governance Index ("NGI") to measure how the enforcement tools deployed in international, EU and national law have changed over time, from the birth of the EU's flagship nature conservation law, the 1992 Habitats Directive (Directive 92/43/EEC). At the national level, we focus on three EU Member States (France, Ireland and the Netherlands) to enable a fine-grained measurement of the changes in national nature governance laws over time. This article introduces our unique datasets and the NGI, describes the process used to collect the datasets and its limitations, and compares the evolution in laws at the international, EU and national levels over the 23-year period from 1992-2015. Our findings provide strong empirical confirmation of the democratic turn in European environmental governance, while revealing the significant divergences between legal systems that remain absent express harmonisation of the Aarhus Convention's principles in EU law. Our data also set the foundations for future quantitative legal research, enabling deeper analysis of the relationships between the different levels of multilevel environmental governance.
\end{abstract}


Keywords Environmental governance $\cdot$ Biodiversity $\cdot$ Nature conservation - Quantitative research $\cdot$ Leximetric approach $\cdot$ EU law $\cdot$ Aarhus convention

\section{Introduction}

European environmental governance has radically transformed over the past two decades. While traditionally enforcement of environmental law has been the responsibility of public authorities (public authorities of the EU Member States, themselves policed by the European Commission), this paradigm has now taken a democratic turn. Led by changes in international environmental law and in particular the UNECE Aarhus Convention (UNECE, 1998), EU law now gives important legal rights to members of the public and environmental non-governmental organisations ("ENGOs") to become involved in environmental governance, by means of accessing environmental information, participating in environmental decision-making and bringing legal proceedings (Kingston et al., 2017). In line with the multilevel nature of the EU's governance system, those principles of "environmental democracy" must be implemented at the national level and transposed into national law by EU Member States, by legislators but also by other legal actors including judges. This embrace of "bottom-up" private environmental governance aims to improve the implementation of environmental law as well as increase accountability and transparency in environmental decision-making by democratising environmental enforcement (Hedemann-Robinson, 2015; European Commission, 2017). These are vital issues, against the background of unprecedented climate and environmental challenges, and ongoing declines in biodiversity in Europe (European Commission, 2020a). Further strengthening the Aarhus principles forms a central commitment of the European Green Deal (European Commission, 2020b).

While doctrinal legal and regulatory scholarship on this embrace of "bottom-up" private environmental governance is now substantial (see, e.g., see Kingston \& Alblas, 2020, and Wurzel et al., 2013), there has been relatively little quantitative research in the field. This is in part because of the challenge of measuring different levels of environmental rules (international, EU, national) and the very wide variety of rules of relevance to environmental governance (e.g., criminal penalties, civil fines, rules on legal standing, and rules on legal costs). This article represents a first step in mapping this evolution of environmental governance laws in the EU. We employ a leximetrics methodology, coding over 6,000 environmental governance laws from three levels of legal sources (international, EU and national), to provide the first systematic data showing the transformation of European environmental governance regimes. We develop the Nature Governance Index ("NGI") to measure how the enforcement tools deployed in international, EU and national law have changed over time, from the birth of the EU's flagship nature conservation law, the 1992 Habitats Directive (Directive 92/43/EEC). At the national level, we focus on three EU Member States (France, Ireland and the Netherlands) ${ }^{1}$ to enable a fine-grained measurement of the changes in national nature governance laws over time.

\footnotetext{
1 Our chosen EU Member States have been selected to give a variety of geographic size of Member State, record of compliance with EU environmental law, legal "family" to which the legal system belongs (common law, civil law), and length of time taken to ratify Europe's groundbreaking international environmental governance treaty, the 1998 UNECE Aarhus Convention (UNECE, 1998). See further, Sect. 3.3 below.
} 
This article introduces our unique datasets and the NGI, describes the process used to collect the datasets and its limitations, and compares the evolution in laws at the international, EU and national levels over the 23-year period from 1992 to 2015. It breaks new ground in providing a close-look quantitative measurement of substantive changes in environmental governance rules over time, mapping three levels of legal hierarchy. Our data also set the foundations for future quantitative legal research, enabling deeper analysis of the relationships between the different levels of multilevel environmental governance. In a forthcoming partner article, this will enable us, for the first time, to quantitatively measure the relationship between these changes in nature governance rules and their effectiveness in practice. In this way, we can also empirically test the extent to which "institutions matter" (North, 1990) in European nature conservation. Finally, we seek to develop quantitative comparative legal research, by developing a more accurate method for quantitative longitudinal comparison of changes in different levels of legal norm in multilevel governance, through a technique that we term inter-jurisdictional normalisation.

\section{Quantifying changes in law over time: the prior literature}

Of the prior literature seeking to quantify changes in law over time, most literature has focussed on corporate governance laws, shareholder protection and competition law (e.g., Armour et al., 2009; Bradford et al., 2019; Buchanan et al., 2014; Lele \& Siems, 2007). A common feature of these studies is the adoption of what can be termed a "leximetric" methodology, understood as the quantitative measurement of law by means of coding legal rules (Lele \& Siems, 2007). In essence this entails (a) compiling a dataset of the laws within the field and jurisdiction studied; (b) developing an index by selecting variables as proxies for quantification of the legal rules at issue; and (c) creating a coding protocol by assigning numeric values to these rules, thus enabling quantification of the legal "strength" of these laws measured in terms of the selected variables. As Deakin (2018: p. 467) observes, this offers an important means of better understanding the development of law, by enabling graphical representations of data which are otherwise complex and hard to access. This is certainly the case for European nature governance laws, where the varying levels of protection in different States can be difficult to understand, in part due to the large number of relevant laws and case-law, the multilevel nature of governance, and the different structures of the legal systems at issue (Kingston et al., 2017).

Proxies of quantification of law have varied. Early studies used relatively blunt proxies to measure legal texts, such as Cooter and Ginsburg's measurement of the "specificity" of legal obligation using the proxy of the length of the legal text at issue (word count) (Cooter \& Ginsburg, 2003). Subsequent studies have adopted a more refined approach to variable selection. For instance, Lele \& Siems (2007) identified two broad categories of variables (protection against board and management, and protection against other shareholders), each with sub-variables, in measuring the degree of shareholder protection in five States over time. Armour et al. (2009) selected ten variables to measure the development of shareholder protection over time across 20 countries and, going a step further, investigated how shareholder protection development influences stock market development. More recently, Bradford et al.'s comparative competition law dataset coded competition law (excluding case-law) from around the world (Bradford et al., 2019), in an effort systematically to measure the global spread of competition law, using six categories of variable including the stated goals of the law at issue, and level of exemptions. 
To date, only a limited number of studies have coded environmental law. These studies have largely focussed on cross-sectional coding of international environmental agreements, based on a dataset that codes the design and degrees of legalisation of international environmental treaties at a specific point in time (CIESIN, 2006; Bernauer et al., 2013; Böhmelt \& Butkute, 2018). Spilker \& Koubi (2016) added a time series dimension to the analysis of international treaties, again focussing on treaty design, contrasting "hardness" and "softness" in international environmental treaties.

Our work goes further than the existing literature in four respects.

First, to enable investigation of enforcement and compliance, we adopt a novel focus on nature governance laws, meaning the legal tools or "architectures" used to promote compliance with nature conservation rules (Heyvaert, 2018: p 31). We develop the "Nature Governance Index" ("NGI”), which constitutes, to our knowledge, the first attempt to quantify the strength of nature governance rules.

Second, a particular novelty of the NGI is that it captures the multilevel nature of environmental governance within Europe, coding laws from three levels of legal source (international, EU and national). This enables comparison of the relationships between changes in the different levels of legal norm since the adoption of the EU's flagship nature conservation law, the Habitats Directive (Directive 92/43/EEC), and will ultimately enable measurement of their respective impacts on the effectiveness of nature governance.

Third, we include all forms of law within our dataset, including legislation and case-law, but also soft law, i.e., law that has a persuasive but not binding legal character within the legal system at issue. This is important in giving a fuller picture of relevant changes in governance rules over time, in particular in the field of European environmental governance where, for instance, the European Commission has frequently issued guidance in the form of Communications and/or Notices, which are not formally binding as a matter of law but are often referenced in case-law (Kingston et al., 2017).

Fourth, in the comparative leximetrics literature to date, we observed that there is continued difficulty in making a proper comparison between the measurement of laws in one State and another. This may arise, for instance, because of the necessarily different structure in the legal systems of each State, meaning that, for instance, there may be numerically a greater number of French laws implementing the Habitats Directive than Irish laws implementing that Directive. Existing studies have variously used standardization (indices with standard deviation of 1) such as in Anderson et al. (2012) and normalisation (indices with minimum value of 0 and maximum value of 1) in Deakin \& Sarkar (2011), or indeed "pure aggregation" without any statistical adjustment (Armour et al., 2009). To address this difficulty, we introduce the approach of inter-jurisdictional normalisation, enabling a more refined comparison between changes in the strength of nature governance rules between jurisdictions.

In developing the NGI, we acknowledge the debate about the appropriateness of using quantitative techniques in studying law, and whether it can be said that transforming complex legal texts into numeric values oversimplifies the complexity of laws and overlooks the inherent subjectivity of legal interpretation. In common with others (e.g., Deakin, 2018: p 462; Freyens \& Verkerke, 2017), we strongly believe in the importance of quantitative analysis of law, as an additional means of "capturing reality", as the premise for all index construction. However, we take account of concerns of oversimplification and subjectivity by: 
(a) Avoiding the conventional approach of constructing a single, aggregated index for laws (Freyens \& Verkerke, 2017), in favour of four sub-indices for measuring different aspects of what we term the strength of the nature governance rules (the traditional governance, access to information, public participation and access to justice sub-indices);

(b) In line with best practice (see, e.g., Bradford et al., 2019), employing a double-blind coding process followed by rigorous quality checks by a third senior legal researcher across the coded legislation, to counteract the problem of coding subjectivity and ensuring maximum objectivity of resultant data;

(c) Adopting a fine-grained approach to coding, avoiding binary approaches (identifying whether the form of law exists, or not) in favour of coding for relevant variations in law over time, including legislation, case-law and soft law;

(d) In line with best practice (OECD, 2008), ensuring transparency of the coding protocol, and use and/or adaptation by future researchers, by making this available for researchers together with our coding data. ${ }^{2}$

\section{Constructing the nature governance index}

\subsection{Defining nature governance rules}

In defining and demarcating nature governance rules, meaning the legal tools used to promote compliance with nature conservation rules, we build upon prior work (Kingston \& Alblas, 2020; Kingston et al., 2017) to distinguish between laws imposing a criminal penalty for breach of a substantive rule; laws imposing a fine for breach of a substantive rule; laws or other rules creating economic incentives to engage in compliance (such as payments and subsidies granted to farmers and landowners for the provision of eco-system services); and laws promoting the principles of transparency, participation and/or access to justice in environmental matters. The last category encompasses the private environmental governance principles set out in the Aarhus Convention, which we term collectively the "Aarhus mechanisms".

We deliberately prefer the term nature governance rules to enforcement rules, as the former term encompasses a broader variety of rules aimed at promoting non-State actor compliance, including rules creating economic incentives to comply, or promoting private environmental governance and the Aarhus mechanisms. In this way, we look beyond traditional enforcement by State bodies or public agencies, recognising that effectiveness of different nature governance rules in achieving compliance increasingly depends on the broader environmental regulatory toolkit available, to harness the regulatory potential of non-State actors such as regulates but also ENGOs and members of the public (European Commission., 2020a; Kingston et al., 2017). We also include governance rules that may apply to all types of environmental governance, as long as they apply to nature governance.

\subsection{Designing the nature governance index}

The NGI comprises four sub-indices aimed at measuring different aspects of what we term the strength of nature governance rules. The first is what we term the "Traditional

2 These data are available at http://effectivenaturelaws.ucd.ie. 
Governance" sub-index, comprising laws providing for criminal penalties (with or without a potential term of imprisonment and/or fine); civil and administrative fines; and financial incentives to comply (including payments and subsidies)). The second, third and fourth sub-indices comprise laws providing for private governance in the form of the Aarhus mechanisms, namely, access to information ("ATI"), public participation ("PP") and access to justice ("ATJ").

We divide these mechanisms into separate sub-indices in order more accurately to chart the strength of the private governance/Aarhus mechanisms over time. Within each sub-index, we identify 6-15 variables, each representing key aspects of that sub-index. In selecting these variables, we had regard to:

(1) The state-of-the-art in scholarship on typologies of regulatory tools employed in environmental compliance and enforcement (see, for instance, the overviews in Kingston et al., 2017 and Wurzel et al., 2013);

(2) Official guidance of relevance to European nature governance, such as relevant Communications for the European Commission in the field (see for instance, European Commission, 2017, 2020a); and.

(3) In the case of the Aarhus mechanisms, the provisions and structure of the Aarhus Convention itself and the core features of that Convention.

Figure 1 depicts the principal components of the NGI. A point of note is that we have included financial payments and subsidies within the sub-index for "traditional governance". We are conscious that, in certain typologies of the environmental regulatory toolbox, such payments/subsidies may be considered to form part of "new" environmental governance/policy instruments rather than more traditional State-imposed criminal/civil penalties and fines (see, e.g., the discussions in Gunningham, 2010, and Wurzel et al., 2013). However, as payments/subsidies are provided by the State, we group payments/ subsidies within traditional governance, in distinction from the sub-indices for each of the Aarhus private governance mechanisms, which are the focus of our work.

\subsection{Selection of legal sources}

We coded nature governance laws from 1992 (the date of adoption of the Habitats Directive) to 2015 inclusive, from five sources: international law, EU law, Irish domestic law, French domestic law and Dutch domestic law. ${ }^{3}$ As Table 1 illustrates, the States were selected to present a variety of geographic size of Member State, environmental conditions and record of compliance with EU environmental law, legal "family" of the State at issue (common law or civil law), and length of time taken to ratify the Aarhus Convention.

In our final database, we coded a total of 6,145 laws, of which 403 comprise international laws, 470 EU laws, 1,161 Irish laws, 2,307 French laws and 1,804 Dutch laws. The database of laws to be coded was compiled by, first, performing a methodical search for the nature governance laws in force within the jurisdiction identified during this 23 -year

\footnotetext{
32015 was the selected end-point both because it marked the commencement of the research project, and left a sufficient gap after the EU's principal legislation implementing the Aarhus Convention, such as the Access to Information Directive (Directive 2003/4/EC) and the Public Participation Directive (2003/35/ EC), to allow for inclusion of national transposing legislation and attendant case-law.
} 


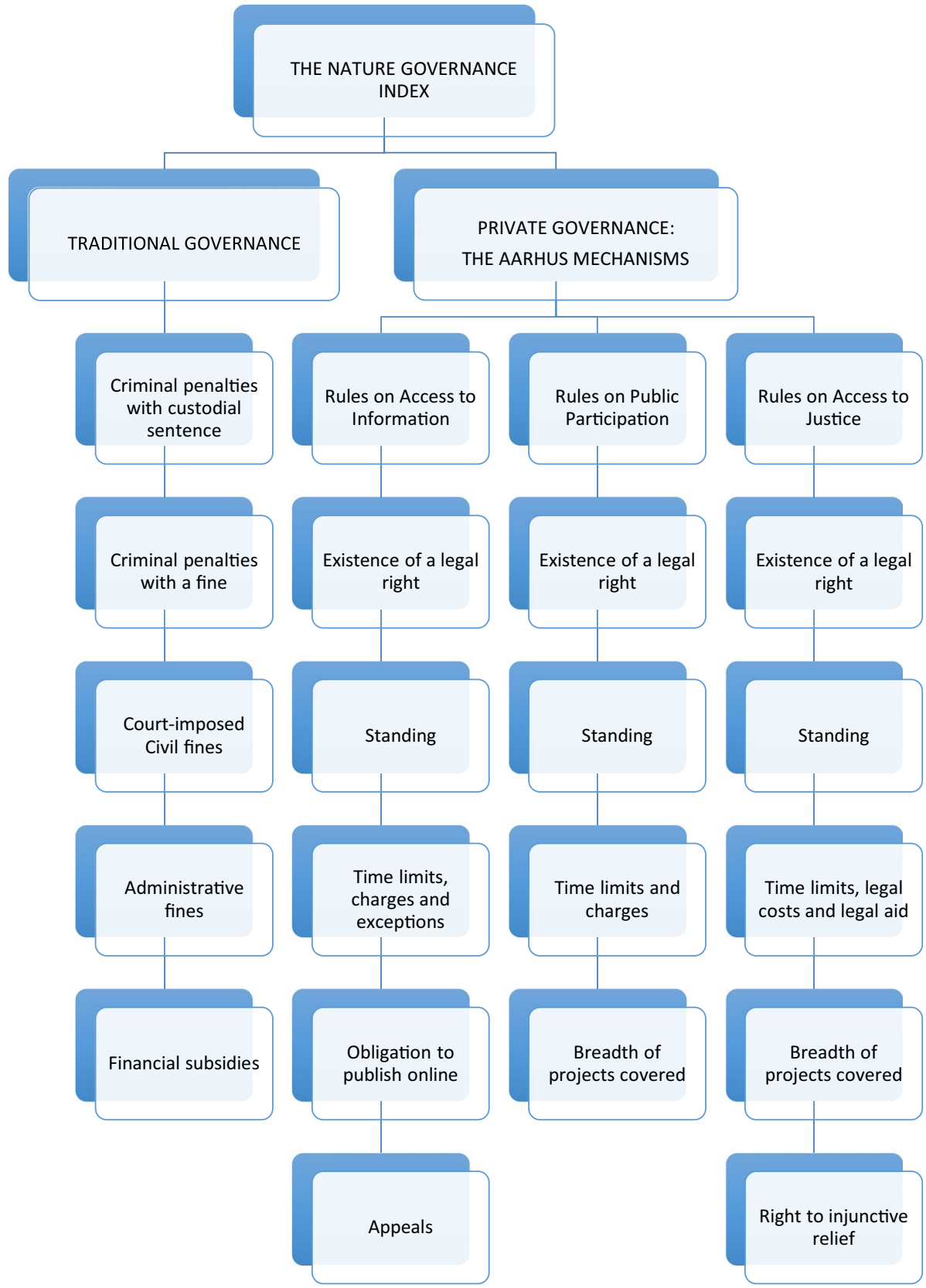

Fig. 1 Construction of the nature governance index 


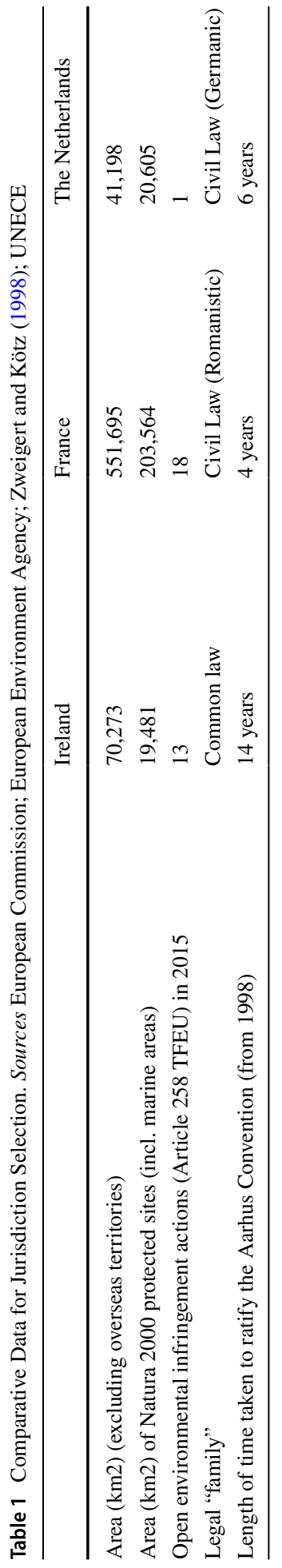


Table 2 Sample extracts from the Nature Governance Laws database

\begin{tabular}{|c|c|}
\hline Jurisdiction/legal source & Sample nature governance laws \\
\hline International law & $\begin{array}{l}\text { Convention on Biological Diversity 1992; Espoo Convention 1997; Aarhus } \\
\text { Convention 1998; } \\
1992 \text { UN Forest Principles; } 1992 \text { Rio Declaration on Environment and Develop- } \\
\text { ment } \\
\text { Nature Governance Case-law of the International Court of Justice; WTO Appel- } \\
\text { late Body; Aarhus Convention Compliance Committee }\end{array}$ \\
\hline EU law & $\begin{array}{l}\text { Directive 92/43/EEC (Habitats Directive); Directive 2003/4/EC and Direc- } \\
\text { tive 2003/35/EC (implementing Aarhus Convention) Directive 2009/147/EU } \\
\text { (Codified Wild Birds Directive); Directive 2010/75/EU (Industrial Emissions } \\
\text { Directive); Directive 2011/92/EU (Environmental Impact Assessment Direc- } \\
\text { tive); LIFE Regulations } \\
\text { Environmental Action Programmes; Commission Communications } \\
\text { Nature Governance Case-law of the Court of Justice of the European Union }\end{array}$ \\
\hline Irish domestic law & $\begin{array}{l}\text { Wildlife Act; Planning and Development Act 2000-2010; Environment } \\
\text { (Miscellaneous Provisions) Act 2011; European Communities (Conservation } \\
\text { of Wild Birds) Regulations; European Communities (Natural Habitats) Regu- } \\
\text { lations; European Communities (Birds and Natural Habitats) Regulations; } \\
\text { Planning and Development Regulations; European Communities (Access to } \\
\text { Information on the Environment) Regulations; Rural Environmental Protection } \\
\text { Scheme Regulations } \\
\text { National Biodiversity Plan } \\
\text { Nature Governance Case-law of the Irish High Court and Supreme Court }\end{array}$ \\
\hline French domestic law & $\begin{array}{l}2005 \text { Charter for Environment; Law } \mathrm{n}^{\circ} 2013-619 \text { of July 16, } 2013 \text { (on sustaina- } \\
\text { ble development); Law }{ }^{\circ} 2010-788 \text { of July 12, } 2010 \text { (Grenelle II); Ordinance } \\
\mathrm{n}^{\circ} 2001-321 \text { of April 11, } 2001 \text { (concerning, inter alia, access to information); } \\
\text { Ordinance No. 2000-914 of September 18, } 2000 \text { (Environmental Code) } \\
\text { National environmental plans } \\
\text { Nature Governance Case-law of the French Constitutional, Ordinary and Admin- } \\
\text { istrative Courts }\end{array}$ \\
\hline Dutch domestic law & $\begin{array}{l}\text { Boswet (Forest law); Natuurschoonwet (Natural scenery law); Natuurbescher- } \\
\text { mingswet } 1998 \text { (Nature protection law); Flora \& Fauna wet (Flora and Fauna } \\
\text { law); Wet Milieubeheer (Environmental Management Law); Kaderwet LNV } \\
\text { subsidies (Framework law for agricultural, nature and fisheries subsidies); Wet } \\
\text { Uitvoering Verdrag van Aarhus (Law implementing the Aarhus Convention); } \\
\text { Algemene wet bestuursrecht (General Administrative Law Act); Wet openbaar- } \\
\text { heid van bestuur (Freedom of Information Act); National environmental plans } \\
\text { Nature Governance Case-law of the District Courts, Courts of Appeal and } \\
\text { Supreme Court }\end{array}$ \\
\hline
\end{tabular}

period, including constitutional law, legislation, case-law, and soft law. Second, in order to ensure that no important nature governance laws had been missed, a cross-check was performed against leading practitioner and academic textbooks and articles in the field. Third, a quality check was performed across all five sources to ensure that a consistent approach had been adopted to inclusion in the database, as detailed further below.

Table 2 presents a sample extract of the database for each of the five sources. ${ }^{4}$

\footnotetext{
4 The full databases can be viewed at http://effectivenaturelaws.ucd.ie.
} 


\subsection{The coding process ${ }^{5}$}

The identified nature governance laws were coded over the course of a 5-year period (2015-2020) by the research team, assisted by over 50 law students and graduates, selected from Irish, French and Dutch universities. The coding was based upon a questionnaire of some 40 questions on the NGI variables, summarised in the Appendix, which was completed by the coders on Qualtrics.com for each of the laws in our nature governance database. The coders were asked to read the legal rule first, then complete the questionnaire based on their understanding of the rule. To minimise the risk of subjectivity of coding, we employed "double-blind" coding whereby each legal rule was assigned to at least two coders, supervised by senior research team members. Upon completion of the two questionnaires for each law, we compared the coders' answers using a Java-based computer programme. Where a different answer to the same question arose, the coders were, in the first instance, asked to discuss the matter with each other to determine who was correct. Where disagreement remained, this was resolved by a senior research team member. Finally, a quality control was performed on all of the coding by a senior research team member at the end of the process. By rigorously following these steps, we aimed to minimise the risk of subjectivity of legal coding highlighted in prior literature (see, e.g., Buchanan et al., 2014).

We employed a graduated non-binary coding scheme to transform the responses to each question into numeric values (for the full coding scheme employed, see Table 4 in the Appendix). In common with prior literature (e.g., Freyes \& Verkerke, 2017), we considered that a binary approach would be overly simplistic and would not adequately capture the complexity of the nature governance rules at issue. In essence, in the case of the traditional governance sub-index, a higher score was assigned where stricter penalties and/or higher payments/subsidies were provided for in law. In the case of the Aarhus private governance sub-indices, a higher score was assigned to laws more fully enabling access to information, public participation and/or access to justice in environmental matters.

In assigning scores in the Aarhus private governance sub-indices, we placed additional weight on one fundamental question, in particular, whether the nature governance rule at issue created a legal right to access to information, public participation and access to justice in the legal system in question. ${ }^{6}$ In doing so, we acknowledge the debate concerning the application of weighting to coding analyses, and the argument that this introduces a further element of subjectivity into the resultant index, although this may be mitigated by ensuring transparency of the weighting applied (e.g., Lele \& Siems, 2007: p 29; Deakin, 2018: p 466). Here, in common with prior literature (e.g., Armour et al., 2009; Bradford et al., 2019) we considered that this very limited application of weighting was justified, in particular as (a) the question whether or not the law confers a legal right to the private governance mechanism at issue is pivotal in understanding the strength of the governance regimes studied; and (b) the number of questions arising from the granular, "close-look" nature of the coding we employed meant that, absent such weighting, this pivotal feature would not have been adequately reflected in the aggregated index, which would have itself cast doubt on the assumptions underlying the index.

\footnotetext{
5 We gratefully acknowledge the insights gained from an international expert methodology workshop held in Dublin, 2016 with invitees from academia, State agencies and ENGOs from across the three Member States in question, which informed our approach to the coding process.

${ }^{6}$ For further detail, see the Appendix. As explained below, we employed an aggregation approach in constructing the index and did not use, for instance, principal-component analysis (PCA) or factor analysis, although PCA is used in the companion econometric paper.
} 
We then aggregated the variables in their numeric form within each sub-index per year and per legal source, to construct 20 continuous variables representing the strength of traditional and private/Aarhus nature governance rules, taking into account only those laws in force in the particular year in question. This enables us to capture the entire set of nature governance laws in force in each of the 23 years in question. We did not exclude from the coding process provisions of national law that transposed international or EU law, because the manner in which that transposition took place, and its timing, was of central interest to us in understanding the ripple effects of international/EU nature governance laws through the national legal system.

\subsection{Normalisation}

As previously noted, we coded 403 international laws, 470 EU laws, 1,161 Irish laws, 2,307 French laws and 1,804 Dutch laws, aggregating the variables within each sub-index. One issue rising from this method is that, since we are not only interested in the trend of development of each sub-index within each jurisdiction, but also in comparing the development of each sub-index across the five jurisdictions, the absolute value of the aggregated index is dependent on the number of laws coded for each jurisdiction. However, ranking based on the absolute values of the indices would be clearly biased, because the number of Dutch and French laws coded was greater than the number of international, EU and Irish laws coded. What might be termed a "pure aggregation" approach is therefore suitable for visualizing the development of environmental governance over time for each index per jurisdiction, but we did not consider it suitable for inter-jurisdictional comparison of developments.

In fact, much of the leximetrics literature to date suffers from the problem that no proper comparison can be made between indices pertaining to different jurisdictions. Existing studies have largely used standardization (indices with standard deviation of 1) (e.g., Anderson et al., 2012), normalisation (indices with minimum value of 0 and maximum value of 1 ) (Deakin \& Sarkar, 2011), or pure aggregation without statistical adjustment (Armour et al., 2009). We therefore develop the literature to suggest a solution to this issue which enhances comparability of indices between jurisdictions, and removes the bias resulting from different absolute numbers of governance laws, which we term "inter-jurisdictional normalization". In this approach, we first aggregate all variables within each index per jurisdiction by year. Using the minimum number of laws in one as the base, we then multiply the values of index for each jurisdiction by this number and divide it by the number of laws for that jurisdiction. Table 3 illustrates the effects of this approach, taking Access to Information (“ATI") as an example.

We do not claim that this enables absolute comparability between jurisdictions: as each jurisdiction may be starting from a different level of recognition of the governance

Table 3 Example of Inter-Jurisdictional Normalisation

\begin{tabular}{lllll}
\hline Jurisdiction & Year & $\begin{array}{l}\text { Number of Laws Pro- } \\
\text { moting ATI coded }\end{array}$ & $\begin{array}{l}\text { Strength of ATI before } \\
\text { normalisation }\end{array}$ & $\begin{array}{l}\text { Strength of ATI } \\
\text { after normalisation }\end{array}$ \\
\hline International law & 2000 & 356 & 36.6 & 30.12 \\
EU law & 2000 & 293 & 62.6 & 62.6 \\
Irish law & 2000 & 643 & 102.35 & 46.64 \\
French law & 2000 & 755 & 106.8 & 41.45 \\
Dutch law & 2000 & 988 & 278.55 & 82.61 \\
\hline
\end{tabular}


mechanisms at the starting point for this study (1992), the trajectory of some jurisdictions will naturally be steeper than others. However, the technique improves comparability, and in particular reduces the bias inherent in the different structure and number of governance laws in force at any one time in each jurisdiction.

\section{Results}

\subsection{Comparing the trajectories of traditional and "new" private governance mechanisms}

Our results strongly confirm the democratic turn in the evolution of European nature governance rules over the past generation and outlined in the Introduction. The left hand graph below (Fig. 2) depicts the normalised trajectories for traditional governance rules in each of the five jurisdictions. The right hand graph depicts the normalised trajectories for the combined private governance, Aarhus mechanisms sub-indices in each jurisdiction.

As Fig. 2 shows, the strength of traditional governance mechanisms has remained relatively stable over the 23-year period for most of our studied jurisdictions. This reflects the fact that, for many States, the essentials of their traditional governance regimes for nature conservation (e.g., applicable criminal sanctions and civil fines for breach, and availability of environmental subsidies to farmers for pro-conservation measures) were broadly speaking in place by 1992, although refinements were certainly made in the intervening years.

Thus, in Dutch law, the Act on Economic Offenses of 1951 stipulating penalties for a range of possible offences relating to nature conservation, the Forestry Act of 1961 with rules and financial incentives regarding forests, and the Natural Scenery Act of 1928 with financial incentives to preserve natural qualities of country estates were already in place by 1992 . However, certain legislation (in particular the Flora and Fauna Act 1999, and the Nature Protection Act 1998) further strengthened the applicable traditional State enforcement framework. In the case of France, a gradual increase can be observed reflecting legislative strengthening through, e.g., the establishment of sanctions for damage to preserved environmental areas (Law $n^{\circ}$ 95-101 relating to the strengthening of environmental protection), and concerning national and regional natural parks and marine natural parks (Law $n^{\circ} 2013-619$ implementing certain EU law requirements in the field of sustainable development), along with related case-law. Conversely, Ireland stands out as a jurisdiction where the strength of traditional governance has increased markedly over this period. This reflects the fact that, as previously noted, the nature governance regimes of our selected jurisdictions were not all at similar levels in 1992
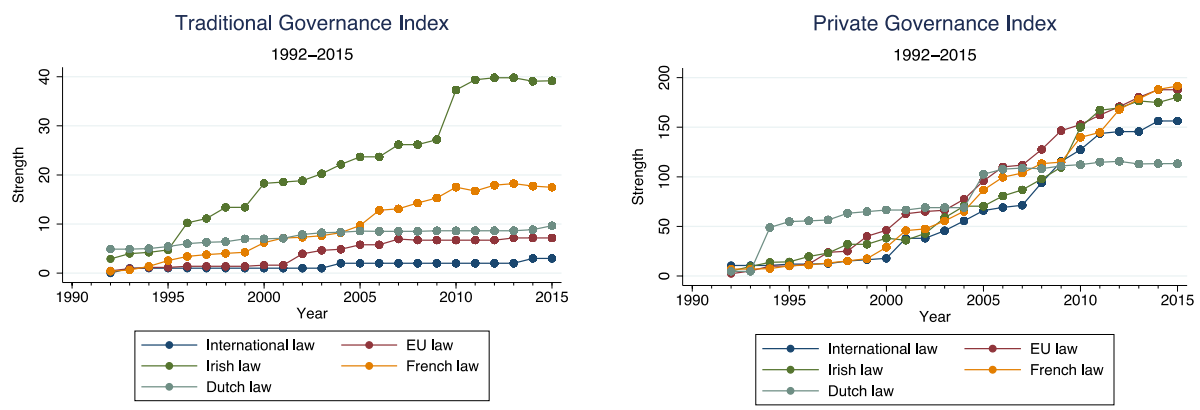

Fig. 2 The NGI-Trends in traditional vs. private governance compared 
(Laffan \& O'Mahony, 2008). For Ireland, the next 23 years saw the passage of many important pieces of environmental legislation, including the Wildlife (Amendment) Act 2000 establishing national protected areas (National Heritage Areas), the Planning and Development Act 2000 which fundamentally reformed Irish planning and land use law, and the passage of a number of Ministerial Regulations transposing elements of the Birds and Habitats Directives.

While the strength of EU and international traditional governance regimes may appear relatively low, this is consistent with the fact that the specifics of how nature law breaches are enforced and punished are typically not provided for in international or EU law, but are left to States to determine (Hedemann-Robinson, 2015; Kingston et al., 2017). Having said that, the slight rise in the EU law trajectory reflects certain legislation passed during this period which harmonised certain aspects of traditional nature governance, including the Environmental Liability Directive (Directive 2004/35/EC), the Framework Decision on the Protection of the Environment through Criminal Law (Framework Decision 2003/80/JHA), and the Directive on Environmental Crime (Directive 2008/99/EC), as well as the increase in relevant nature funding (e.g., through the LIFE scheme) over the period.

This relative stability of the studied traditional nature governance regimes from 1992 to 2015 stands in contrast to the marked increase in the strength of private / Aarhus governance mechanisms across all jurisdictions during this period. Here, the normalised graphs disclose that, for most of the jurisdictions, the steady increase in strength of private governance regimes did not start in earnest until after the signature of the Aarhus Convention in 1998. In the case of international law, this reflects, for instance, the case-by-case interpretation and strengthening of the Convention by the decisions of the Aarhus Convention Compliance Committee which, although not formally a Court, has since its creation in 2002 dealt with increasingly large numbers of communications from members of the public in respect of Contracting Party States, and has not shied away from issuing decisions of potentially major constitutional significance (Kingston et al., 2017; Samvel, 2020).

As concerns EU law, the steady increase in strength reflects the EU's decision to incorporate the Aarhus principles into EU law by means of the Access to Information Directive (Directive 2003/4/EC), the Public Participation Directive (2003/35/EC), the Decision concluding the Aarhus Convention on the part of the EU (Decision 2005/370/EC), and the Aarhus Regulation applying the Aarhus principles to the EU's own institutions (Regulation 1367/2006), as well as important case-law of the EU courts giving strong interpretations to the implications of the Aarhus Convention for the EU's legal order, discussed further below. French and Irish law followed broadly parallel trajectories to EU law, reflecting the fact that these States were not generally first-movers in incorporating private nature governance norms within their governance laws, but rather did so after signature of the Convention (as in France, such as the introduction of rules giving rights of public participation and affording special recognition to certain ENGOs (agrément) in 2000), or after the Convention's intervening incorporation into EU law (as in Ireland). In Ireland's case, it did not itself ratify the Aarhus Convention until 2012, and was the last EU Member State to do so. Despite this, it was required to transpose the Aarhus principles into its national environmental law long before this, insofar as those principles were incorporated into EU law.

The outlier trajectory is that of the Netherlands, where the strength of private nature governance rules increased and remained high even before signature of the Convention. This reflects the fact that the essence of the Aarhus principles of access to environmental information, public participation and access to justice were already to an extent present in Dutch law with, for instance, the entry into force of the Environmental Protection Act in 1993, and the General Administrative Law Act 1994 which inter alia codified ENGOs' 
right of access to the courts. In this way, our graphs reveal that private governance was, as a matter of law, already well-established in the Netherlands prior to Aarhus.

\subsection{Comparing the different private governance mechanisms: the effects of (lack of) EU harmonisation writ large}

Our results graphically depict the difference that imposing a mandatory governance requirement in EU law, as distinct from issuing non-binding "soft law" EU guidance, makes in harmonising national standards. While the EU has applied all three pillars of the Aarhus Convention to its own institutions via the so-called "Aarhus Regulation" (Regulation 1367/2006, currently being revised), its express incorporation of the Aarhus Convention vis-à-vis its Member States has been only partial. The EU passed Directives on access to environmental information (Directive 2003/4) and on public participation (Directive 2003/35) just five years after the Convention was signed in 1998, but no agreement could be reached on passage of an access to environmental justice Directive. In fact, despite the efforts of the European Commission over some 20 years, Member States have strongly resisted enshrining rights of access to environmental justice expressly in EU legislation (Kingston et al., 2017: ch. 5), leaving the Commission confined to publishing non-binding guidance on the matter (European Commission, 2017, 2020b) save in certain limited fields such as environmental impact assessment and industrial emissions. This has led to a situation where, over 20 years after the Convention's signature, the European Commission concluded in 2020 that a "series of systemic shortcomings" persist in the implementation of access to environmental justice in practice, including difficulties faced by ENGOs in obtaining legal standing to bring legal challenges on EU environmental issues, and prohibitively high costs (European Commission, 2020b: 2).

Figure 3 illustrates the substantial effects that this lack of harmonisation of access to justice provisions has had in practice. Whereas the NGI Aarhus sub-indices increase largely in lockstep for the five jurisdictions in the case of public participation and access to information, ${ }^{7}$ the spread of trajectories is markedly wider for access to justice. This is so even despite the CJEU's effort to indirectly increase the effectiveness of the Aarhus access to justice requirements by ruling that, even though these requirements had not been incorporated into the Habitats Directive, national courts were nonetheless obliged to interpret their national procedural rules "in a way which, to the fullest extent possible" is consistent with the aims of the Convention (CJEU, 2011, Slovak Brown Bear). Further, and surprisingly, this important effect of EU level harmonisation occurs even though all three Member States are separately bound by the Aarhus Convention as a matter of international law, with the Netherlands ratifying in 2004, France in 2002 and Ireland in 2012.

Our results therefore strongly support the view that the effects of soft law, even when reinforced by a strong Court-imposed interpretative obligation to interpret national law "to the fullest extent possible" in line with that soft law, is far weaker than binding legal requirements, at least in the sensitive area of national rules on access to justice. They therefore confirm that, in the European Commission's continued quest to strengthen access to environmental justice within Member States, express legislation remains the "holy grail". This is, indeed, consistent with the European Commission's recent express plea to the EU co-legislators (i.e.,

\footnotetext{
7 Some differences still arise here from 2010 onwards, which may be explained by the fact that certain States had chosen to go further than the minimum requirements of EU law, thus diluting the relative impact of EU-level harmonisation. For instance, the Netherlands was a first-mover in the case of access to information and already had robust laws in place before EU legislation (see Sect. 4.1); and the principle of public participation was constitutionalised in France in 2005 (see below).
} 
Fig. 3 The NGI-Trends in access to information, public participation and access to justice compared

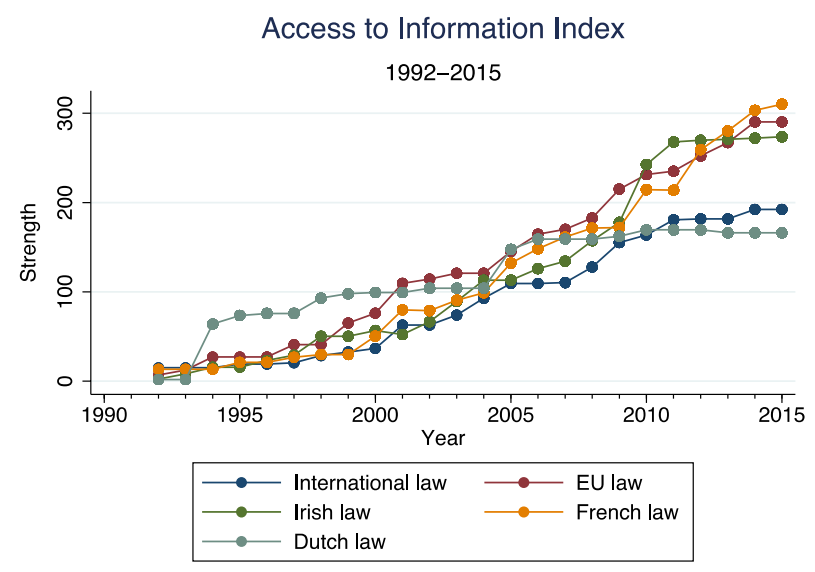

Public Participation Index

1992-2015

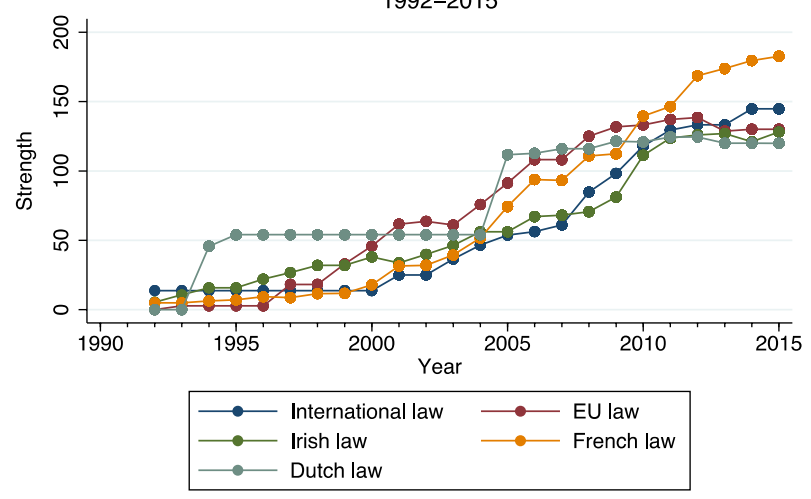

Access to Justice Index

1992-2015

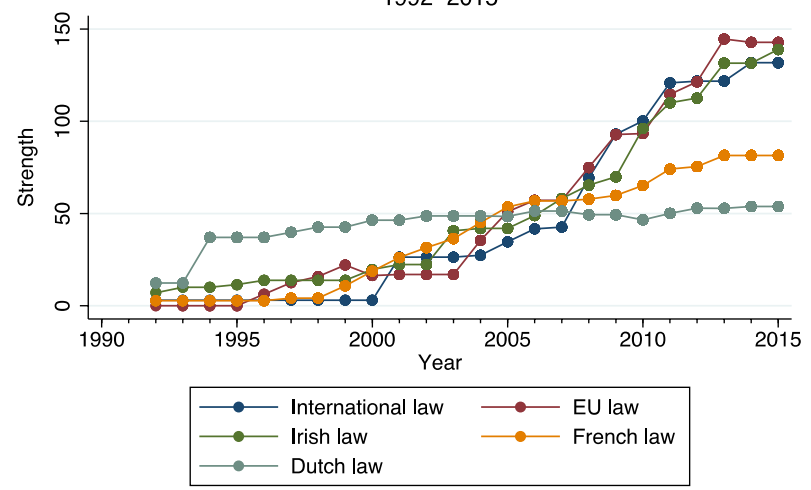

the Council and the European Parliament) to include express access to justice provisions in binding new or revised EU environmental laws (European Commission, 2020b: p 8). Of note, however, is that the EU has itself largely rejected the Aarhus Convention Compliance 
Fig. 4 The NGI - trends in Dutch access to justice
NL Access to Justice

1992-2015

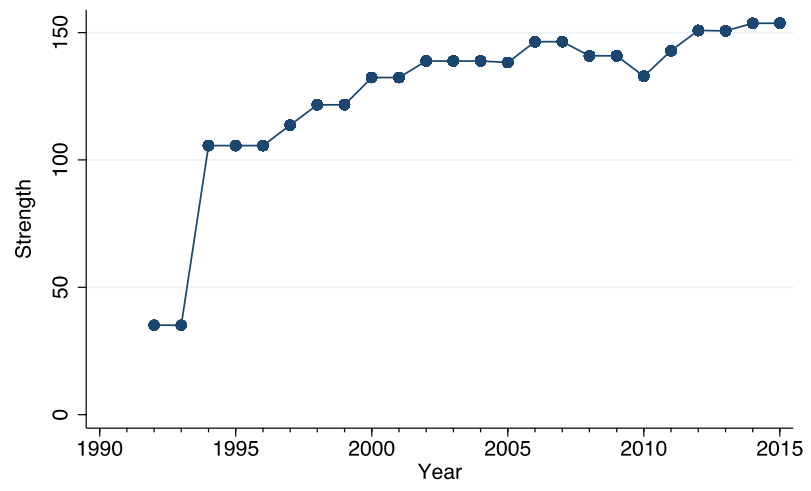

Access to Information Index 1992-2015

Case Law

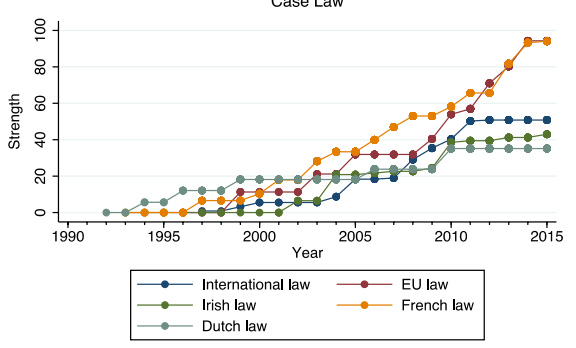

Access to Justice Index 1992-2015

Case Law

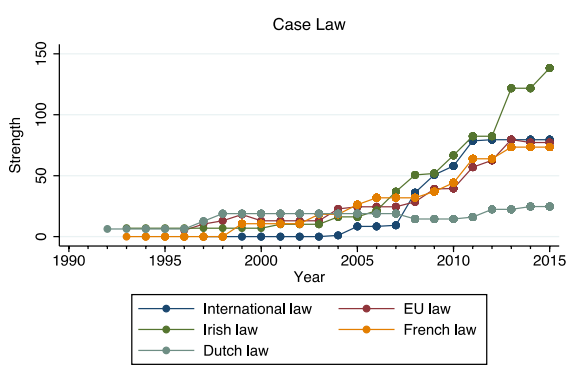

Fig. 5 The NGI-The Role of Case-Law

Committee's findings that the EU's own legal system is non-compliant with the Convention's access to justice requirements (ACCC/2008/32/EU, Part 1 and Part 2).

Our results also graphically illustrate the fact that, where a Member State already had strong values of transparency, access to information, public participation and access to justice in its legal system, the Aarhus Convention and its incorporation into EU law has made far less difference. This is the case with the Netherlands, for instance, where each of the three Aarhus sub-indices displays a jump well before the Aarhus Convention was signed, underlining that the Netherlands was a first-mover in this area. This reflects the passage of important environment-specific laws (such as the Wet Milieubeheer in 1993) as well as generally applicable laws increasing transparency, public participation and/or access to justice which also apply to nature governance, such as the General Administrative Law Act 1994 and the Freedom of Information Act 1992.

Interestingly, where such legal values were already well-embedded in the legal system prior to the passage of the Convention and implementing EU law (as in the Netherlands), our results show an ultimate "plateau-ing" of the NGI trajectory, even when EU law and case-law may continue to deliver incremental clarification of what is required by the Aarhus principles. This suggests that, as the Aarhus principles were already familiar and long-established as domestic norms, the Dutch legislator and judiciary did not consider there to be the same need to constantly adapt and react to changes within the EU legal order and case-by-case developments in the CJEU jurisprudence.

Conversely, taking the example of Ireland, our results show that the relationship of Irish law with the Aarhus principles is largely reactive, taking its cue from developments further 
implementing those principles within the EU legal order (encompassing legislation and caselaw), giving rise to a characteristic tracking of the shape of the EU sub-indices. This was subject to a time-lag: for instance, the Irish rules implementing Directive 2003/4/EC on access to environmental information were introduced in 2007. As our results demonstrate, this reactive approach may mean that national governance rules at times increase in strength at a steeper trajectory than other States, with the intermediation of EU rules pushing the Member State to increase the strength of its governance rules (as with access to justice, where the Irish trajectory is steeper than that of the Netherlands and France). At other times, such reactive approach may mean that the State does not go beyond the minimum EU requirements, even where other States are going further (as with public participation for instance, in comparison with the steeper trajectory of the French index, in circumstances where the principle of public participation was given constitutional status by integrating the Charte de l'environnement into the preamble of the Constitution in 2005, and subsequent judicial decisions applying that principle).

Of further note is that, while overall the trend in all three Aarhus NGI sub-indices was (gradually) upward, this was not always so. A case in point is the access to justice trajectory in the Netherlands where, after a major jump in 1993 due to the entry into force of the Environmental Protection Act (including express access to justice provisions for matters covered by that Act) and the General Administrative Law Act (codifying access to courts for ENGOs and setting down general locus standi requirements), the overall strength diminished between 2008 and 2012, due to a more restrictive approach adopted in the caselaw (Fig. 4). That restrictive approach was, however, abandoned by the courts from 2012 onwards, restoring the sub-index to its prior level.

\subsection{Comparing the development of case-law and the role of judges in the evolution of private nature governance}

Finally, our results also show the specific role of judges in the evolution of private nature governance in the selected jurisdictions. By extracting the trajectories in case-law over the period, separately from legislation and soft law, this reveals a fascinating difference in judicial approaches over this period. Our results reveal that, where governance rules are harmonised by express legislation, there is significantly less scope for court rulings to make a difference, whether by means of the use of "strong" interpretative techniques such as those required by the CJEU's Slovak Brown Bear ruling mentioned above, or otherwise.

Thus, taking access to information as an example (Fig. 5), the curve for Ireland and the Netherlands remains relatively stable, in circumstances where the applicable domestic legislative rules effectively codified the area leaving little scope for judicial "activism". By contrast, the steep trajectory for France illustrates that constitutionalising environmental governance norms (here, via the Charte de l'environnement) can have powerful effects on judicial decision-making, even in a civil law jurisdiction such as France.

On the other hand, in the case of access to justice (Fig. 5), the notably steep trajectory of Irish case-law reflects the relatively open-textured nature of the environmental costs rules in Ireland, whereby the standard rule of "costs follow the event" (loser pays) was displaced in 2010-2011 in favour of a rule that requires each side to bear its own costs in environmental litigation, but conferring discretion upon judges to award environmental applicants their costs (so-called "one-way costs shifting"). That discretion, combined with the robust CJEU caselaw on the obligation to interpret national environmental law to the fullest extent possible, led to a striking increase in the strength of Irish nature governance case-law from 2010 to 2015. Our results suggest, therefore, that the determinative factor in the trajectory and strength of 
case-law in the nature governance field is not, as one might expect, whether the legal system in question has a common law or civil law tradition. Rather, the extent to which the wording of the national legislation is open-textured and leaves room for judicial interpretation-or, conversely, densely codified—makes a far greater difference.

\section{Conclusion}

Improving enforcement of the EU's nature laws is at the heart of the EU's 2030 Biodiversity Strategy, and is acknowledged by the European Commission as essential in dealing with Europe's biodiversity crisis (European Commission, 2020a). The Aarhus Convention, and its empowering of private governance by enabling civil society enforcement through law, has been a cornerstone of Europe's environmental enforcement strategy for the past generation.

This article represents the first attempt to quantitatively assess this transformation in European environmental governance, applying leximetrics theory to code over 6,100 laws from five jurisdictions, in a five-year process involving a team of over 50 coders. We also seek to develop quantitative comparative legal research, by coding not only legislation but also case-law and soft law, and by developing a more accurate method for quantitative longitudinal comparison of changes in legal norms in a multilevel governance system, through the inter-jurisdictional normalisation technique outlined above.

Our findings provide strong empirical confirmation of the democratic turn in European environmental governance. Our results reveal that, contrary to what might be assumed, Europe's private governance revolution has not been at the expense of traditional governance techniques, such as strengthening of criminal sanctions and civil/administrative fines. Rather, private governance has evolved alongside traditional mechanisms, especially at the national level. Digging deeper into the Aarhus mechanisms, our findings show striking differences between States' approach to nature governance and the impact of EU law in this field, ranging from first-mover (the Netherlands), reactive (Ireland), or something in between (France). Ultimately, however, they strongly confirm that, even when Member States are themselves independently bound by the Convention as a matter of international law, important divergences between national governance laws will remain, absent express harmonisation in EU law. Nor does the CJEU's forceful case-law imposing a strong interpretative obligation fill this gap, although it makes the most difference to national judges where national governance norms are open-textured.

We do not, of course, claim that NGI replaces or obviates the need for traditional legal scholarship analysing these legal developments using doctrinal methodology. It is a complement to these doctrinal approaches. By developing the NGI, our goal is to create a new tool enabling a more objective and rigorous analysis of comparative trends in nature governance laws in Europe over the past 23 years, and the relationships between different levels of Europe's multilevel governance. We also seek to lay the foundation for future quantitative research and, in a forthcoming partner article, we use the NGI to test the impacts of this private governance revolution in practice, by regressing the index against indicators of these laws' practical effects, and levels of economic growth. It is our hope that, by publishing the NGI and attendant datasets, this inspires further empirical research in this vital area.

\section{Appendix}

See Table 4. 
Table 4 Nature governance index coding protocol

\section{Traditional Nature Governance Index}

1. Criminal penalty with custodial sentence

2. Criminal penalty with fine

3. Criminal penalty with possibility of damages

4. Civil fine

5. Administrative fine

6. Financial incentive

\section{Access to Information Index}

1. Implementation of Aarhus Convention

2. Aim

3. Public / privately held information

4. Legal right

5. Beneficiary

6. Time limits

7. Cost

8. Scope of Exceptions

9. Format

10. Appeal

11. Cost of appeal
Possibility of criminal penalty with custodial sentence $=6$; No possibility $=0$

Maximum sentence from $<6$ months to +6 years $=$ Graduated scale of between 1 and 6 applied; Unspecified $=0$

Possibility of a criminal penalty with a fine $=5$; No fine $=0$

Maximum fine from $€ 1$ (or national currency equivalent) to $+€ 1$ million $=$ Graduated scale of between 0.5 and 5 applied; None specified $=0$

Possibility of a criminal penalty with damages $=4$; No possibility $=0$

Possibility of court-imposed civil (non-criminal) fine/ penalty $=3$; No possibility $=0$

Possibility of an administrative fine/penalty in the case of breach; No possibility $=0$

Maximum administrative fine $€ 1$ (or national currency equivalent) to $+€ 1$ million $=$ Graduated scale of $0.2-2$ applied; None specified $=0$

Financial incentive for pro-environmental behaviour $=1$; None $=0$

Maximum incentive $€ 1$ (or national currency equivalent) to $+€ 1$ million $=$ Graduated scale of $0.1-1$ applied; None specified $=0$

Created to implement the Convention $=1 ; \mathrm{No} /$ unclear $=0$

Aim of increasing access to information $=1 ; \mathrm{No} /$ unclear $=0$

Applies to public \& privately held information $=1$; Only public or private $=0.5$

Creates legal right of access $=5 ; \mathrm{No} /$ unclear $=0$

Information available to public in general without need to request; to public in general upon request; to only certain members of the public upon request; Graduated scale of between 1 and 0 applied

Clear timeline for provision $=1$; None $=0$

Information to be provided as soon as possible; 1 month or less after a request; 2 months or less after a request +2 months after a request. Graduated scale of $1-0$ applied

No charge for access $=1$; Charge $=0$

Charge of $€ 20-+€ 60$; Graduated scale of 1-0 applied

Graduated scale of 1-0 applied according to breadth of exceptions to right accorded

Information to be publicly available online $=1$; Not specified $=0$

Graduated scale of 1-0 if decision can be challenged by court / court or administrative body / not subject to challenge

No charge $=1$; Charge $=0$

Graduated scale of $1-0$ if cost of appeal is $<€ 20$ to $+€ 60$ 
Table 4 (continued)

\section{Public Participation Index}

1. Implementation of Aarhus Convention

2. Aim

3. Legal right

4. Scope of rule

5. Beneficiary

6. Deadline

7. Cost of public participation

8. Impact of observations

9. Duty to inform the public

\section{Access to Justice Index}

1. Implementation of Aarhus Convention

2. Aim

3. Legal right

4. Scope of rule

5. Legal standing for individuals

6. Legal standing for ENGOs

7. Substantive/Procedural legality

8. Availability of interim relief

9. Limitation period

10. Costs

11. Discretion in costs

12. Protective Costs

13. Legal aid

14. Accessibility of information

15. Cost of information
Created to implement the Convention $=1 ; \mathrm{No} /$ unclear $=0$

Aim of increasing public participation $=1 ;$ No/unclear $=0$

Creates legal right of participation $=5$; No/unclear $=0$

Graduated scale of 1-0 applied according to scope of projects / activities covered (broader, equal to or narrower than Directive 2003/35/EC)

Graduated scale of 1-0 applied according to scope of beneficiary (broader, equal to or narrower than Directive 2003/35/EC)

Graduated scale of $1-0$ applied according to timeline for participation (broader, equal to or narrower than Directive 2003/35/EC)

No charge for participation $=1$; Charge $=0$

Graduated scale of 1-0 applied according to level of charge applied

Legal duty to take observations into account $=1$; None $=0$

Legal duty to inform participating public of decision $=1$; None $=0$

Created to implement the Convention $=1 ; \mathrm{No} /$ unclear $=0$

Aim of increasing access to justice $=1 ;$ No/unclear $=0$

Creates legal right of access to justice $=5 ; \mathrm{No} /$ unclear $=0$

Graduated scale of 1-0 applied according to scope of projects/activities covered (broader, equal to or narrower than Directive 2003/35/EC)

Graduated scale of $1-0$ applied according to whether substantive right, sufficient interest, or broader standing rule applied

Graduated scale of 1-0 applied according to whether substantive right, sufficient interest, or broader standing rule applied

Graduated scale of 1-0 applied according to whether solely procedural legality may be challenged, or substantive and procedural legality

Injunctive/interim relief available $=1 ;$ None $=0$

Graduated scale of 1-0 applied depending on length of limitation period for bringing a claim

More favourable costs regime for environmental claims $=1 ;$ None $=0$

Graduated scale of 1-0 applied depending if applicants' award of costs conditional on judicial discretion

Protective Costs Order possible $=1$; Not possible $=0$

Legal aid provided for environmental claimants $=1$; Not provided $=0$

Information on Access to Justice must be made available to public $=1$; No such requirement $=0$

Decisions on environmental matters must be publicly accessible free of charge $=1$; No such requirement $=0$ 
Acknowledgements We gratefully acknowledge funding from the European Research Council project (ERC) under the European Union's Horizon 2020 research and innovation programme (grant agreement No 639084) for the five-year project investigating the effectiveness of the EU's nature governance rules of which this research forms part. We also gratefully acknowledge the contributions of the participants in the Effective Nature Laws high-level expert workshop in Dublin, 2016 and more than 50 research assistants from University College Dublin and partner universities in France and The Netherlands, who have helped in the process of compiling the database and indices.

Funding Open Access funding provided by the IReL Consortium.

Open Access This article is licensed under a Creative Commons Attribution 4.0 International License, which permits use, sharing, adaptation, distribution and reproduction in any medium or format, as long as you give appropriate credit to the original author(s) and the source, provide a link to the Creative Commons licence, and indicate if changes were made. The images or other third party material in this article are included in the article's Creative Commons licence, unless indicated otherwise in a credit line to the material. If material is not included in the article's Creative Commons licence and your intended use is not permitted by statutory regulation or exceeds the permitted use, you will need to obtain permission directly from the copyright holder. To view a copy of this licence, visit http://creativecommons.org/licenses/by/4.0/.

\section{References}

Anderson, H., Welsh, M., Ramsay, I., \& Gahan, P. (2012). The evolution of shareholder and creditor protection in Australia: An international comparison. The International and Comparative Law Quarterly, 61(1), 171-207.

Armour, J., Deakin, S., Sarkar, P., Siems, M., \& Singh, A. (2009). Shareholder protection and stock market development: An empirical test of the legal origins hypothesis. Journal of Empirical Legal Studies, $6(2), 343-380$.

Bernauer, T., Kalbhenn, A., Koubi, V., \& Spilker, G. (2013). Is there a depth versus participation dilemma in international cooperation? Review of International Organizations, 8(4), 477-497.

Böhmelt, T., \& Butkute, E. (2018). The self-selection of democracies into treaty design: Insights from international environmental agreements. International Environmental Agreements, 18, 351-367.

Bradford, A., Chilton, A. S., Megaw, C., \& Sokol, N. (2019). Competition law gone global: Introducing the comparative competition law and enforcement datasets. Journal of Empirical Legal Studies, 16, 411-443.

Buchanan, J. H., Chai, D., \& Deakin, S. (2014). Empirical analysis of legal institutions and institutional change: Multiple-methods approaches and their application to corporate governance research. Journal of Institutional Economics, 10(1), 1-20.

Centre for International Earth Science Information Network (CIESIN). (2006). Environmental treaties and resource indicators. Retrieved 1 March 2021 from http://sedac.ciesin.columbia.edu/entri/.

CJEU (2011). Case C-240/09 Lesoochranárske zoskupenie VLK v Ministerstvo životného prostredia Slovenskej republiky (“Slovak Brown Bear") ECLI:EU:C:2011:125.

Cooter, R. \& Ginsburg, T. (2003). Leximetrics: Why the Same Laws are Longer in Some Countries than Others. University of Illinois Law \& Economics Research Paper No. LE03-012, available at SSRN: https://ssrn.com/abstract $=456520$.

Deakin, S. (2018). The use of quantitative methods in labour law research: An assessment and reformulation. Social \& Legal Studies, 27(4), 456-474.

Deakin, S., \& Sarkar, P. (2011). Indian labour law and its impact on unemployment, 1973-2006: A leximetric study. Indian Journal of Labour Economics, 53, 607-629.

European Commission. (2017). Communication by the Commission: Commission Notice on Access to Justice in Environmental Matters, C(2017) 2616.

European Commission (2020a). EU Biodiversity Strategy for 2030, Bringing Nature Back Into Our Lives, $\operatorname{COM}(2020) 380$.

European Commission (2020b). Communication on Improving access to justice in environmental matters in the EU and its Member States, $\operatorname{COM}(2020) 643$.

Freyes, B., \& Verkerke, J. (2017). Mapping employment dismissal law: A leximetric investigation of EPL stringency and regulatory style International Labour Office. ILO.

Gunningham, N. (2010). Enforcement and compliance strategies. In R. Baldwin, M. Cave, \& M. Lodge (Eds.), The Oxford handbook of regulation (pp. 120-146). Oxford University Press. 
Heyvaert, V. (2018). Transnational environmental regulation and governance: Purpose, strategies and principles. Cambridge University Press.

Hedemann-Robinson, M. (2015). Enforcement of EU environmental law. Routledge.

Kingston, S., Heyvaert, V., \& Čavoški, A. (2017). European environmental law. Cambridge University Press.

Kingston, S., \& Alblas, E. (2020). Of the people, by the people, for the people? The European Union's experience with private environmental regulation and enforcement. In M. De Cock Buning \& L. Senden (Eds.), Private regulation and enforcement in the EU (pp. 165-190). Hart Publishing.

Laffan, B., \& O'Mahony, J. (2008). Bringing politics back in'. Domestic conflict and the negotiated implementation of EU nature conservation legislation in Ireland. Journal of Environmental Policy \& Planning, 10, 175-197.

Lele, P., \& Siems, M. (2007). Shareholder protection: A leximetric approach. Journal of Corporate Law Studies, 7(1), 17-50.

OECD (2008). Handbook on constructing composite indicators. Methodology and user guide. OECD.

Samvel, G. (2020). Non-judicial, advisory, yet impactful? The Aarhus convention compliance committee as a gateway to environmental justice. Transnational Environmental Law, 9(2), 211-238.

Spilker, G., \& Koubi, V. (2016). The effects of treaty legality and domestic institutional hurdles on environmental treaty ratification. International Environmental Agreements, 16, 223-238.

North, D. (1990). Institutions, institutional change and economic performance. Cambridge University Press.

United Nations Economic Commission for Europe Convention (1998). Convention on access to information, public participation in decision-making and Access to Justice in Environmental Matters (the Aarhus Convention), signed on June 25, 1998.

Wurzel, R., Zito, A., \& Jordan, A. (2013). Environmental governance in Europe: A comparative analysis of new environmental policy instruments. Elgar.

Zweigert, K., \& Kötz, H. (1998). An introduction to comparative law. Oxford University Press.

Publisher's Note Springer Nature remains neutral with regard to jurisdictional claims in published maps and institutional affiliations.

\section{Authors and Affiliations}

\section{Suzanne Kingston ${ }^{1}$ (D) Zizhen Wang ${ }^{2}$ - Edwin Alblas ${ }^{1} \cdot$ Micheál Callaghan ${ }^{1}$. Julie Foulon ${ }^{1}$. Valesca Lima ${ }^{3}$. Geraldine Murphy ${ }^{4}$}

Suzanne Kingston

suzanne.kingston@ucd.ie

Zizhen Wang

wangzizhen@xmu.edu.cn

Edwin Alblas

edwin.alblas@ucdconnect.ie

Micheál Callaghan

micheal.callaghan@ucdconnect.ie

Julie Foulon

julie.foulon@ucdconnect.ie

Valesca Lima

valesca.lima@mu.ie

1 University College Dublin, Sutherland School of Law, Dublin, Ireland

2 Xiamen University, Xiamen, China

3 Maynooth University, Maynooth, Ireland

4 Dublin, Ireland 